\title{
Suzuki-Miyaura Coupling between 3-Iodolawsone and Arylboronic Acids. Synthesis of Lapachol Analogues with Antineoplastic and Antileishmanial Activities
}

\author{
Sara L. S. Gomes, ${ }^{a, b}$ Gardenia C. G. Militão, ${ }^{c}$ Arinice M. Costa, ${ }^{d}$ Cláudia Ó. Pessoa,,${ }^{d e}$ \\ Letícia V. Costa-Lotufo, ${ }^{f}$ Edézio F. Cunha-Junior, ${ }^{g}$ Eduardo C. Torres-Santos, ${ }^{g}$ \\ Paulo R. R. Costa ${ }^{a}$ and Alcides J. M. da Silva ${ }^{*, b}$ \\ ${ }^{a}$ Laboratório de Química Bioorgânica and ${ }^{b}$ Laboratório de Catálise Orgânica, \\ Instituto de Pesquisas de Produtos Naturais, Universidade Federal do Rio de Janeiro, \\ 21941-590 Rio de Janeiro-RJ, Brazil \\ ${ }^{c}$ Departamento de Fisiologia e Farmacologia, Universidade Federal de Pernambuco, \\ 50670-901 Recife-PE, Brazil \\ ${ }^{d}$ Departamento de Fisiologia e Farmacologia, Universidade Federal do Ceará, \\ 60430-270 Fortaleza-CE, Brazil \\ eInstituto Oswaldo Cruz, FIOCRUZ-CE, 60180-900 Fortaleza-CE, Brazil \\ ${ }^{f}$ Departamento de Farmacologia, Universidade de São Paulo, 05508-900 São Paulo-SP, Brazil \\ ${ }^{8}$ Laboratório de Bioquímica de Tripanosomatídeos, Instituto Oswaldo Cruz, FIOCRUZ-RJ, \\ 21040-900 Rio de Janeiro-RJ, Brazil
}

\begin{abstract}
A series of 2-hydroxy-3-arylnaphthalene-1,4-diones (3-aryllawsones) were synthesized by Suzuki-Miyaura cross coupling reaction of 3-iodolawsone with arylboronic acids/esters. The hydroxylated resulting products were transformed into their corresponding $N, N$-diethyl carbamates. The antineoplastic and antileishmanial activities of the compounds were evaluated and compared with lapachol and its carbamate, providing promising results.
\end{abstract}

Keywords: Suzuki-Miyaura coupling, lapachol analogues, pd-catalysis

\section{Introduction}

Quinones are present in many naturally occurring compounds, and are responsible for taking part in the life cycle of many living organisms. ${ }^{1}$ They are well known for being significant source of biologically active compounds. ${ }^{2}$ For example, the benzoquinone mitomycin $\mathrm{C}^{3}$ and the anthraquinone doxorubicin ${ }^{4}$ are relevant members of this family, being used in clinic as antineoplastic agents (Figure 1).

Among the quinone family, naphthalene-1,4-diones is the most important class with many representatives such as synthetic atovaquone, ${ }^{5}$ that is used in anti-malarial therapy and chemoprophylaxis of malaria; the naturally occurring 2-hydroxy-3-prenylnaphthalene-1,4-dione lapachol (1), first isolated by E. Paterno from Tabebuia avellanedae in 1882 exhibiting antimalarial, antifungal, antitumor,

*e-mail: alcides@nppn.ufrj.br leishmanicidal, bactericidal and antiparasitic activities; ${ }^{6}$ and the antibiotic WS-5995-C, ${ }^{7}$ a functionalized naphthalene1,4-dione isolated from Streptomyces auranticolor species, that possess chemoprotective activity against Eimeria tenella (Figure 1). Eiremia tenella is a protozoan disease that causes poultry coccidiosis impacting directly in chicken industry and global food supply due to the high mortability. ${ }^{8}$

Lapachol (1) has been used as starting point to obtain new bioactive quinones showing interesting pharmacological profiles. ${ }^{9,10}$ Herein, we would like to report the synthesis of 2-hydroxy-3-arylnaphthalene-1,4-diones, analogues of WS-5995-C that can also be considered analogues of $\mathbf{1}$ in which the prenyl side chain is substituted by an aromatic ring (Figure 1). We rationalized the use of the aromatic ring in a way to mimic the $\pi$-system of $\mathbf{1}$, knowing that prenyl and phenyl can be considered isosteres. ${ }^{11}$

Carbamates are widely used in organic synthesis as protecting groups and they have been found in the 


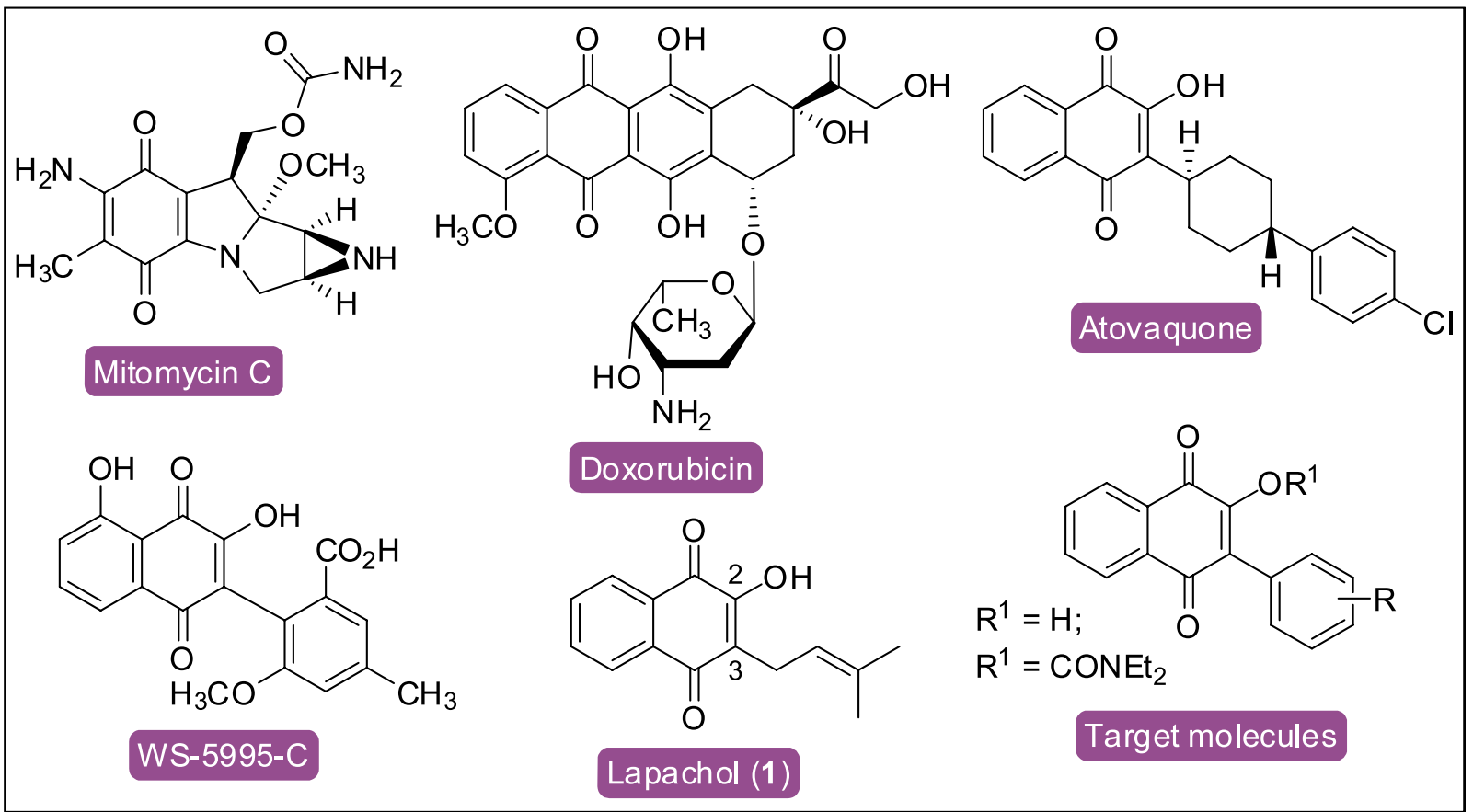

Figure 1. Natural and synthetic compounds from quinone family.

structure of promising antiviral, antifungal, antibacterial, antimicrobial and anticancer molecules. ${ }^{12}$ Organic carbamates can act as an electrophilic site, alkylating biological nucleophiles, ${ }^{13}$ having their use also correlated to prodrug design. ${ }^{14}$ These precedents prompted us to synthesize new potentially active analogues combining the 2-hydroxy-3-arylnaphthalene-1,4-dione scaffold and the carbamate function, aiming to obtain compounds with dual action.

The antineoplastic and antileishmanial activities of these compounds were evaluated and the results compared with 1. Cancer cells and protozoan parasites are known to possess several biochemical similarities and to share mutual features such as highly proliferative behavior and resistance to the programmed cell death. Therefore, antineoplastic and antileishmanial agents have common biological targets that act on enzymes inhibition of both parasite and human cells enabling apoptosis. ${ }^{15}$

\section{Results and Discussion}

\section{Chemistry}

Few general methods are available in literature to prepare 2-hydroxy-3-arylnaphthalene-1,4-diones such as: $(i)$ the palladium catalyzed Stille-type coupling involving phenyliodonium ylides of hydroxyquinones and naphthopyranyl stannanes; ${ }^{16}$ (ii) the palladium catalyzed Suzuki-type coupling of phenyliodonium ylides of hydroxyquinones with arylboronic acids; ${ }^{17}$ (iii) the metal free arylation of 2-hydroxy-naphthalene-1,4-diones with phenyliodonium ylides mediated by $\mathrm{BF}_{3},{ }^{18}$ (iv) the oxidative arylation of 2-hydroxy-naphthalene-1,4-diones using $o$-iodoxybenzoic acid and phenylhydrazines; ${ }^{19}$ and (v) $\mathrm{K}_{2} \mathrm{~S}_{2} \mathrm{O}_{8}$-catalyzed direct $\mathrm{C}-\mathrm{H}$ functionalization of 2-hydroxy-naphthalene-1,4-diones with arylboronic acids. ${ }^{20}$ The main disadvantages associated with the described methods involve the use of hypervalent iodines, that confront the atom economy principle of the green chemistry; employment of toxic hydrazines and scope limitation. In this paper we take advantage of the SuzukiMiyaura cross coupling reaction ${ }^{21}$ to achieve 2-hydroxy3-arylnaphthalene-1,4-diones structurally related to $\mathbf{1}$. After the submission of this paper, Louvis et al. ${ }^{22}$ reported a similar method to synthesize 2-hydroxy-3-arylnaphthalene1,4-diones.

We began with the preparation of the starting material according to the phenol iodination method previously described by our group, in which 2-hydroxynaphthalene1,4-dione was easily iodinated by using a morpholineiodine complex as the iodinating agent. ${ }^{23}$

With the starting material in hands, we first examined the reaction of 2-hydroxy-3-iodonaphthalene-1,4-dione $\mathbf{2}$ with phenylboronic acid $\mathbf{3 a}$ leading to $\mathbf{4 a}$ under the classical Suzuki-Miyaura conditions, ${ }^{21}$ but moderate yield was obtained (Table 1, entry 1).

Taking into consideration that the steric hindrance present in $\mathbf{2}$ may be a problem, we looked for protocols 
Table 1. Optimization of the reaction conditions<smiles>O=C1C(O)=C(I)C(=O)c2ccccc21</smiles>

2 $\underset{\text { solvent, temp., } 18 \mathrm{~h}}{\stackrel{[\mathrm{Pd}]-\text { source, base }}{\longrightarrow}}$<smiles>O=C1C(O)=C(c2ccccc2)C(=O)c2ccccc21</smiles>

$4 a$

\begin{tabular}{|c|c|c|c|c|c|}
\hline entry $^{\mathrm{a}}$ & {$[\mathrm{Pd}]$-source } & Base & Solvent & Temperature $/{ }^{\circ} \mathrm{C}$ & Yield $/ \%$ \\
\hline 1 & $\mathrm{Pd}\left(\mathrm{PPh}_{3}\right)_{4}(5 \mathrm{~mol} \%)$ & $\mathrm{Na}_{2} \mathrm{CO}_{3}$ & DME & 85 & 54 \\
\hline 2 & $\mathrm{Pd}\left(\mathrm{PPh}_{3}\right)_{4}(2 \mathrm{~mol} \%)$ & $\mathrm{K}_{3} \mathrm{PO}_{4}$ & DMF & 110 & 0 \\
\hline 3 & $10 \% \mathrm{Pd} / \mathrm{C}(5 \mathrm{~mol} \%)$ & $\mathrm{K}_{2} \mathrm{CO}_{3}$ & Dioxane- $\mathrm{H}_{2} \mathrm{O}$ & 95 & 96 \\
\hline $4^{c}$ & $10 \% \mathrm{Pd} / \mathrm{C}(5 \mathrm{~mol} \%)$ & $\mathrm{K}_{2} \mathrm{CO}_{3}$ & Dioxane- $\mathrm{H}_{2} \mathrm{O}$ & 95 & 80 \\
\hline 5 & $10 \% \mathrm{Pd} / \mathrm{C}(10 \mathrm{~mol} \%)$ & $\mathrm{K}_{2} \mathrm{CO}_{3}$ & Dioxane- $\mathrm{H}_{2} \mathrm{O}$ & 95 & 89 \\
\hline 6 & $10 \% \mathrm{Pd} / \mathrm{C}(1 \mathrm{~mol} \%)$ & $\mathrm{K}_{2} \mathrm{CO}_{3}$ & Dioxane- $\mathrm{H}_{2} \mathrm{O}$ & 95 & 85 \\
\hline $7^{\mathrm{d}}$ & $10 \% \mathrm{Pd} / \mathrm{C}(5 \mathrm{~mol} \%)$ & $\mathrm{K}_{2} \mathrm{CO}_{3}$ & Dioxane- $\mathrm{H}_{2} \mathrm{O}$ & 95 & 85 \\
\hline
\end{tabular}

${ }^{\mathrm{a}}$ All the reactions were carried out under a nitrogen atmosphere and heated overnight; ${ }^{\text {bisolated yields; } \text { ' } r e a c t i o n ~ c a r r i e d ~ o u t ~ u s i n g ~ 5,5-d i m e t h y l-2-p h e n y l-~}$ 1,3,2-dioxaborinane as the coupling partner; 'experiment done with 1.4 equivalents of 3. DME: 1,2-dimethoxyethane; DMF: $N, N$-dimethylformamide.

that could be better suited on this system, for example, the one reported by Suzuki and Miyaura applying $\mathrm{K}_{3} \mathrm{PO}_{4}$ as base and DMF ( $N, N$-dimethylformamide) as solvent. ${ }^{24}$ However, no product was detected under these conditions (Table 1, entry 2). When conditions described by Blanchet and co-workers ${ }^{25}$ were tested, which involves the use of the cheap catalyst $10 \% \mathrm{Pd} / \mathrm{C}, \mathbf{4 a}$ was achieved in almost quantitative yield (Table 1, entry 3). The evaluation of the performance of arylboronic ester 5,5-dimethyl-2-phenyl1,3,2-dioxaborinane under Blanchet's conditions was also accomplished (Table 1, entry 4).

Further optimization was performed. Increasing the catalyst load from 5 to $10 \mathrm{~mol} \%$ resulted in a drop of the chemical yield (Table 1, entry 5). When diminishing the catalyst amount to $1 \mathrm{~mol} \%$, the yield also suffered a decrease (Table 1, entry 6). Excess of $\mathbf{3}$ was reduced from 2 equivalents to 1.4 equivalents, but a lower yield was obtained (Table 1, entry 7). In this way, optimal conditions were assumed as being the one described in entry 3 .

Aiming to exploit the reactivity of the naphthoquinone system, we protected the free hydroxyl of 2-hydroxy3-iodonaphthalene-1,4-dione (2) using groups with two different electronic demands. Therefore, 2-methoxy3-iodonaphthalene-1,4-dione (5) and 3-iodo-1,4-dioxo1,4-dihydronaphthalen-2-yl acetate (6), were prepared from 2 by the reaction with dimethyl sulfate ${ }^{26}$ and acetic anhydride ${ }^{27}$ respectively. These compounds were then submitted to the optimized conditions described above and on both reactions we observed that a loss of the protecting group had occurred. Performing the reaction with $\mathbf{5}$, compound 4a was provided in $47 \%$ yield; while the reaction with $\mathbf{6}$ led to $35 \%$ yield of $\mathbf{4 a}$.

Next, we examined the scope of this transformation and the results are presented in Table 2.

Moderate yields were obtained when (3,4-dimethoxyphenyl)boronic acid and (4-formylphenyl) boronic acid were employed (4b and $\mathbf{4 e}$ ). Aryl boronates containing fluoro substituents furnished good yields $(\mathbf{4 c}$ and 4d), however, aromatic boronates ortho-substituted were not tolerated on this process, probably due to steric effects (4f-g). From these results we found that the best substrate was the one with no substitution pattern (4a).

Continuing the work, lapachol (1) and analogs 4a-e were transformed into their corresponding $N, N$-diethyl carbamates $\mathbf{8}$ and $\mathbf{7 a - e}$, respectively, according to the well-known protocol described in literature,$^{28}$ furnishing moderate yields (Table 3).

With lapachol analogs in hands, we evaluated their pharmacological profiles in relation to antineoplastic and antileishmanial activities.

\section{Antineoplastic activity}

The antineoplastic activity of the prepared naphthoquinones was studied in two human leukemia cell lines, HL-60 (promyelocytic leukemia) and K562 (chronic myelogenous leukemia), ${ }^{29}$ and the results are shown in Table 4.

Lapachol (1) presented moderate potency against these cell lines (entry 1) and the exchange of the allyl group 
<smiles>COC1=C(I)C(=O)c2ccccc2C1=O</smiles>
5 $3 \mathbf{a}$<smiles></smiles>

$3 a$<smiles>O=C1C(O)=C(c2ccccc2)C(=O)c2ccccc21</smiles>

$4 a$

$47 \%$ yield<smiles>O=C1C(O)=C(c2ccccc2)C(=O)c2ccccc21</smiles>

$4 a$

$35 \%$ yield

Scheme 1. Analyzing the reactivity of the naphthoquinone system.

Table 2. Scope of the reaction<smiles>[R]OC(=O)C1=C(O)C(=O)c2ccccc2C1=O</smiles>

aReaction conditions: 3 (2 equiv.), 10\% $\mathrm{Pd} / \mathrm{C}(5 \mathrm{~mol} \%), \mathrm{K}_{2} \mathrm{CO}_{3}$ (4 equiv.), dioxane/ $\mathrm{H}_{2} \mathrm{O}(1: 1.2), 95{ }^{\circ} \mathrm{C}, 18 \mathrm{~h}$, carried under a nitrogen atmosphere; b5,5-dimethyl-2-(4-(trifluoromethyl)phenyl)-1,3,2-dioxaborinane was used as the coupling partner.

in $\mathbf{1}$ by aryl groups, as in $\mathbf{4 a - c}$ and $\mathbf{4 e}$, led to products still less active (entries 2-4 and 6). Interestingly, $4 \mathbf{d}$ bearing a $p-\mathrm{CF}_{3} \mathrm{Ph}$ substituent, was six to seven times more potent than 1 for both cell lines (entry 5).
The results obtained with carbamates 8 and $7 \mathbf{a}-\mathbf{e}$ are shown in entries 7-12. For HL-60, 8 was still less potent while in K562 the carbamate of lapachol exhibited moderate potency (entry 7). The corresponding carbamates 
Table 3. Carbamates synthesis<smiles>CCOC(=O)C1=C(OCC)C(=O)c2ccccc2C1=O</smiles>

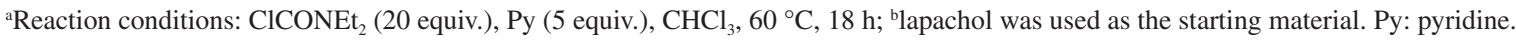

Table 4. Antineoplastic activity of compounds $\mathbf{1}, \mathbf{4 a - e}, \mathbf{7 a - e}$ and $\mathbf{8}$ in HL-60 and $\mathrm{K} 562\left(\mathrm{IC}_{50}, \mu \mathrm{M}\right)$. Doxorubicin (D) was used as reference

\begin{tabular}{lccc}
\hline entry $^{\mathrm{a}}$ & Compound & HL-60 & K-562 \\
\hline 1 & $\mathbf{1}$ & 12.0 & 16.0 \\
2 & $\mathbf{4 a}$ & $>80$ & $>80$ \\
3 & $\mathbf{4 b}$ & $>80$ & $>80$ \\
4 & $\mathbf{4 c}$ & 46.3 & $>80$ \\
5 & $\mathbf{4 d}$ & 2.5 & 2.2 \\
6 & $\mathbf{4 e}$ & $>80$ & $>80$ \\
7 & $\mathbf{8}$ & 35.7 & 9.9 \\
8 & $\mathbf{7 a}$ & 2.3 & 5.4 \\
9 & $\mathbf{7 b}$ & 4.3 & 6.1 \\
10 & $\mathbf{7 c}$ & 1.9 & 1.4 \\
11 & $\mathbf{7 d}$ & 6.9 & 11.4 \\
12 & $\mathbf{7 e}$ & 2.6 & 1.4 \\
13 & $\mathrm{D}$ & 0.04 & 0.14 \\
\hline
\end{tabular}

${ }^{a}$ Data represent the means of three independent experiments, with each concentration tested in duplicate.

of 4a-c, compounds 7a-c (entries 8-10), showed enhanced cytotoxic activity when compared to lapachol $\mathbf{1}$. In contrast, for $\mathbf{4 d}$, the corresponding carbamate $\mathbf{7 d}$ presented a slight lower potency (entry 11), while 7e was much more potent than $4 \mathbf{e}$ (entry 12 ).
PBMC (peripheral blood mononuclear cell) tests were performed only with compounds which presented $\mathrm{IC}_{50}<10 \mu \mathrm{M}$ for tumor cells HL-60 and K562 (Table 5).

The best selectivity indexes were found for compound $\mathbf{4 d}$ (entry 2) followed by compound $\mathbf{7 c}$ (entry 5). In contrast, compound 7d showed no selectivity toward HL-60 or K562 (entry 6).

Compounds $\mathbf{4 d}$ and $\mathbf{7 c}$ are promising. Studies aiming to establish the probable mechanism of action of these compounds are under investigation.

Antileishmanial activity

In the antileishmanial assay, $\mathbf{1}$ showed to be moderately active against promastigotes of $L$. amazonensis, but the $\mathrm{IC}_{50}$ in amastigotes was above the highest concentration tested (Table 6, entry 1). The $\mathrm{IC}_{50}$ in intracellular amastigote, which is the most clinically relevant form for treatment, is the criteria to select hit and lead compounds in drug discovery for leishmaniasis. ${ }^{30}$

The substitution of prenyl for an aromatic ring in $\mathbf{4 a - b}$ led to increased potency against amastigote forms and reduction of toxicity to the macrophages. No significant 
Table 5. Cytotoxic effect of compounds 1, 4d and 7a-e tested in PBMC. Doxorubicin (D) was used as positive control

\begin{tabular}{|c|c|c|c|c|}
\hline entry & Compound & PBMC & PBMC/HL60 $\left(\mathrm{IC}_{50} / \mu \mathrm{M}\right)^{\mathrm{a}}$ & $\mathrm{PBMC} / \mathrm{K} 562\left(\mathrm{IC}_{50} / \mu \mathrm{M}\right)^{\mathrm{b}}$ \\
\hline 1 & 1 & $>80$ & ND & ND \\
\hline 2 & $4 d$ & 78 & 31.2 & 35.4 \\
\hline 3 & $7 a$ & 13.7 & 5.9 & 2.5 \\
\hline 4 & $7 b$ & 34.0 & 7.9 & 5.6 \\
\hline 5 & $7 \mathrm{c}$ & 24.0 & 12.6 & 17.1 \\
\hline 6 & 7d & 11.7 & 1.7 & 1.02 \\
\hline 7 & $7 e$ & 9.4 & 3.6 & 6.7 \\
\hline 8 & $\mathrm{D}$ & 1.78 & 44.5 & 12.7 \\
\hline
\end{tabular}

a Data represent the ratio between PBMC and HL-60 $\mathrm{IC}_{50}$ values. The $\mathrm{IC}_{50}$ values for HL-60 are described in Table 4; bdata represent the ratio between PBMC and $\mathrm{K}_{562} \mathrm{IC}_{50}$ values. The $\mathrm{IC}_{50}$ values for $\mathrm{K} 562$ are described in Table 4. ND: not determined.

Table 6. Antileishmanial activity of compounds 1, 4a-e, 7a-d and $\mathbf{8}$ in promastigotes and intracellular amastigotes of Leishmania amazonensis and toxicity to murine macrophages. Pentamidine was used as reference

\begin{tabular}{|c|c|c|c|c|c|}
\hline entry $^{a}$ & Compound & Promastigote $\mathrm{IC}_{50} / \mu \mathrm{M}$ & Amastigote $\mathrm{IC}_{50} / \mu \mathrm{M}$ & Macrophage $\mathrm{LD}_{50} / \mu \mathrm{M}$ & Selectivity index (SI) \\
\hline 1 & 1 & 18.5 & $>50$ & 74.3 & ND \\
\hline 2 & $4 a$ & 85.8 & 25.0 & 115.2 & 4.6 \\
\hline 3 & $4 b$ & $>100$ & 21.3 & 152.3 & 7.15 \\
\hline 4 & $4 c$ & 70.5 & $>50$ & 90.5 & ND \\
\hline 5 & $4 d$ & 25.5 & 17.2 & 37.5 & 2.1 \\
\hline 6 & $4 e$ & $>100$ & 21.5 & 57.5 & 2.6 \\
\hline 7 & 8 & 2.90 & 4.5 & 15.1 & 3.3 \\
\hline 8 & $7 a$ & 1.98 & 3.6 & 10.2 & 2.8 \\
\hline 9 & $7 \mathrm{~b}$ & 3.0 & 1.5 & 8.0 & 5.3 \\
\hline 10 & $7 c$ & 4.5 & 1.9 & 5.2 & 2.7 \\
\hline 11 & $7 d$ & 3.3 & 2.6 & 4.9 & 1.9 \\
\hline 12 & pentamidine & 1.3 & 0.9 & 41.5 & 46.1 \\
\hline
\end{tabular}

${ }^{\mathrm{a}}$ Data represent the ratio between macrophage $\mathrm{LD}_{50}$ and $\mathrm{IC}_{50}$ in amastigote values. ND: not determined.

alteration was observed for promastigote forms (entries 2 and 3). Interestingly, this modification improved the antiamastigote activity, making $\mathbf{4 b}$ the compound with the most favorable selectivity index (SI) (i.e., many times more selective against intracellular amastigotes than host cells; calculated using the $\mathrm{LD}_{50} / \mathrm{IC}_{50}$ ratios), ${ }^{30}$ although presenting moderate potency. Compounds $\mathbf{4 c - e}$ showed moderate activity against amastigotes and increased toxicity to the macrophages (entries 4-6). The addition of the carbamate function in the structure of $\mathbf{1}$, originating 8, potentiated the antileishmanial activity; however the toxicity to macrophages was also increased (entry 7). Carbamates 7a-d, in which both carbamate and aromatic ring were added to lapachol core, were much more active (entries 8-11). Compound $\mathbf{7 b}$ was the most potent against intracellular amastigotes, with $\mathrm{IC}_{50}$ as low as $1.5 \mu \mathrm{M}$ and selectivity index of 5.3 (entry 9). These data suggest that replacing the prenyl side chain of $\mathbf{1}$ by an aromatic ring is important to enhance the selectivity, while the introduction of the carbamate group is important to enhance the antileishmanial activity.

\section{Conclusions}

Despite the number of methods already existing to produce 3-aryllawsones, all of them have considerable drawbacks making it necessary the search for new synthetic tools. We developed a simple approach to achieve 2-hydroxy-3-arylnaphthalene-1,4-dione (4a-e) in moderate to good yields, involving the palladium-catalyzed Suzuki-Miyaura cross coupling reaction of arylboronic acids/esters (3a-e) and 2-hydroxy-3-iodonaphthalene1,4-dione (2). Unfortunately, ortho-substituted boronates were not tolerated. 
The corresponding carbamates 7a-e were also obtained in moderate yields and all synthesized products were submitted to anticancer and antileishmanial evaluation, for the first time, providing promising results. Molecules $\mathbf{4 d}$ and $\mathbf{7 c}$ showed good activity against cancer cell lines and compound $\mathbf{4 b}$ exhibited good antiamastigote performance. The introduction of the carbamate moiety was important to potentiate the anticancer and antileishmanial activities but also increased the toxicity of the molecules to healthy cells.

\section{Experimental}

\section{Chemistry}

All solvents and chemicals were used as received from commercial sources. Flash column chromatography was carried out using SiliaFlash ${ }^{\circledR}$ F60 silica gel (particle size: 40-63 $\mu \mathrm{m}, 230-400$ mesh, Silicycle, Quebec City). Infrared (IR) spectra were performed on a Shimadzu IRPrestige-21 FT-IR instrument via ATR unit or as $\mathrm{KBr}$ pellets. ${ }^{1} \mathrm{H}$ and ${ }^{13} \mathrm{C}$ nuclear magnetic resonance (NMR) spectra were recorded either on Varian $400 \mathrm{MHz}$ or $500 \mathrm{MHz}$ NMR spectrometer using tetramethylsilane (TMS) as reference. The high resolution mass spectra were acquired by LC-MS (liquid chromatography mass spectrometry) in the ESI (+) mode.

General procedure for the preparation of 2-hydroxy3-iodonaphthalene-1,4-dione (2) ${ }^{23}$

A mixture of 2-hydroxy-naphthalene-1,4-dione ( 1 equiv, $5.74 \mathrm{mmol}$ ) and $\mathrm{K}_{2} \mathrm{CO}_{3}(3.05$ equiv, $17.5 \mathrm{mmol}$ ) in $\mathrm{H}_{2} \mathrm{O}(58 \mathrm{~mL})$ was stirred at room temperature for 10 minutes. After this time, the morpholine-iodine complex $^{23}$ (1.95 equiv, $11.2 \mathrm{mmol}$ ) was slowly added, in similar portions, every 15 minutes during 2 hours and then the reaction was allowed to stir for 3 more days. The reaction mixture was cooled to $0{ }^{\circ} \mathrm{C}$, acidified with $25 \%$ phosphoric acid solution until $\mathrm{pH}$ ca. 2 and placed on refrigerator for 24 hours. The resulting precipitate was filtered under vacuum, washed with $\mathrm{H}_{2} \mathrm{O}$ and purified by recrystallization from glacial acetic acid. This compound was obtained as a yellow solid in 55\% yield, mp 178-180 ${ }^{\circ} \mathrm{C}$; IR (KBr) v / $\mathrm{cm}^{-1} 3200,1666$, $1620,1581,1354,1259,1116,721$; ${ }^{1} \mathrm{H}$ NMR $(400 \mathrm{MHz}$, $\left.\mathrm{CDCl}_{3}\right) \delta 8.21(\mathrm{dd}, 1 \mathrm{H}, J$ 7.0, $1.7 \mathrm{~Hz}, \mathrm{Ar}-\mathrm{H}), 8.15(\mathrm{dd}$, $1 \mathrm{H}, J$ 7.0, $1.7 \mathrm{~Hz}, \mathrm{Ar}-\mathrm{H}), 7.76(\mathrm{~m}, 2 \mathrm{H}, 2 \mathrm{Ar}-\mathrm{H}) ;{ }^{13} \mathrm{C} \mathrm{NMR}$ $\left(101 \mathrm{MHz},\left(\mathrm{CD}_{3}\right)_{2} \mathrm{CO}\right) \delta 180.09,178.02,162.29,135.51$, 134.34, 132.18, 130.47, 128.05, 127.37, 92.59.
General procedure for the preparation of 2-hydroxy3-arylnaphthalene-1,4-diones (4a-e)

A stirred solution of $\mathbf{2}$ ( 1 equiv, $0.5 \mathrm{mmol}$ ), arylboronic acids or esters 3 ( 2 equiv, $1 \mathrm{mmol}$ ), $\mathrm{K}_{2} \mathrm{CO}_{3}$ ( 4 equiv, $2 \mathrm{mmol}$ ) and $\mathrm{Pd} / \mathrm{C} 10 \mathrm{~mol} \%$ (5 mol\%) in dioxane $/ \mathrm{H}_{2} \mathrm{O}$ in proportion of $1: 1.2(11.9 \mathrm{~mL})$ was heated at $95{ }^{\circ} \mathrm{C}$ for 18 hours under nitrogen atmosphere. Dichloromethane $(50 \mathrm{~mL})$ was added to the reaction mixture and the organic layer was first washed with a solution of hydrochloric acid $1 \mathrm{~N}(50 \mathrm{~mL})$ and then with brine $(3 \times 50 \mathrm{~mL})$, dried over anhydrous $\mathrm{Na}_{2} \mathrm{SO}_{4}$ and concentrated in vacuo. The crude product was purified by flash column chromatography on silica gel.

\section{2-Hydroxy-3-phenyInaphthalene-1,4-dione (4a) ${ }^{31}$}

After column chromatography using hexanes/EtOAc (95:5) as eluent, this compound was obtained as an orange solid in 96\% yield, mp $135-137{ }^{\circ} \mathrm{C}$; IR $(\mathrm{KBr}) \mathrm{v} / \mathrm{cm}^{-1}$ 3346, 3049, 1655, 1587 1365, 1331, 1274, 1000; ${ }^{1} \mathrm{H}$ NMR $\left(500 \mathrm{MHz}, \mathrm{CDCl}_{3},\right) \delta 8.21$ (dd, 1H, J 7.6, $\left.0.8 \mathrm{~Hz}, \mathrm{Ar}-\mathrm{H}\right)$, 8.16 (dd, 1H, J 7.6, $0.8 \mathrm{~Hz}$, Ar-H), 7.82 (td, 1H, J 7.5, $1.3 \mathrm{~Hz}, \mathrm{Ar}-\mathrm{H}), 7.75$ (td, $1 \mathrm{H}, J$ 7.5, $1.3 \mathrm{~Hz}, \mathrm{Ar}-\mathrm{H}$ ), 7.58 (s, $1 \mathrm{H}, \mathrm{OH}), 7.54-7.50(\mathrm{~m}, 2 \mathrm{H}, 2 \mathrm{Ar}-\mathrm{H}), 7.50-7.45(\mathrm{~m}, 2 \mathrm{H}$, 2Ar-H), 7.43-7.39 (m, 1H, Ar-H); ${ }^{13} \mathrm{C}$ NMR (126 MHz, $\left.\mathrm{CDCl}_{3}\right) \delta 183.82,181.92,152.33,135.39,133.25,132.87$, $130.73,130.03,129.37,128.76,128.02,127.37,126.23$, 122.22 .

2-(3,4-Dimethoxyphenyl)-3-hydroxynaphthalene-1,4-dione $(\mathbf{4 b})^{31}$

After column chromatography using hexanes/EtOAc (75:25) as eluent, this compound was obtained as a brown solid in $46 \%$ yield, $\mathrm{mp} 174-176{ }^{\circ} \mathrm{C}$; IR $(\mathrm{KBr}) \mathrm{v} / \mathrm{cm}^{-1} 3368$, 1653, 1630, 1585, 1518, 1369, 1259, 1148, 1015; ${ }^{1} \mathrm{H}$ NMR $\left(500 \mathrm{MHz}, \mathrm{CDCl}_{3}\right) \delta 8.10(\mathrm{dd}, 1 \mathrm{H}, J 7.7,0.8 \mathrm{~Hz}, \mathrm{Ar}-\mathrm{H})$, 8.13 (dd, $1 \mathrm{H}, J$ 7.6, $1.0 \mathrm{~Hz}$, Ar-H), 7.80 (td, 1H, J 7.6, $1.3 \mathrm{~Hz}, \mathrm{Ar}-\mathrm{H}$ ), 7.72 (td, 1H, J 7.5, 1.2 Hz, Ar-H), 7.65 (s, $1 \mathrm{H}, \mathrm{OH}), 7.15$ (dd, $1 \mathrm{H}, J$ 8.3, $2.0 \mathrm{~Hz}, \mathrm{Ar}-\mathrm{H}), 7.10(\mathrm{~d}, 1 \mathrm{H}$, $J 1.9 \mathrm{~Hz}, \mathrm{Ar}-\mathrm{H}$ ), 6.96 (d, 1H, J 8.4 Hz, Ar-H), 3.92 (s, 3H, $\left.\mathrm{OCH}_{3}\right), 3.90$ (s, $\left.3 \mathrm{H}, \mathrm{OCH}_{3}\right) ;{ }^{13} \mathrm{C} \mathrm{NMR}\left(126 \mathrm{MHz}, \mathrm{CDCl}_{3}\right)$ $\delta 184.10,181.82,152.05,149.49,148.40,135.30,133.25$, $132.93,129.41,127.36,126.17,124.07,122.44,122.04$, 114.06, 110.68, 56.04, 55.98 .

2-(4-Fluorophenyl)-3-hydroxynaphthalene-1,4-dione (4c) $)^{32}$ After column chromatography using hexanes/EtOAc (90:10) as eluent, this compound was obtained as a yellow solid in $76 \%$ yield, $\mathrm{mp} 183-186{ }^{\circ} \mathrm{C}$; IR $(\mathrm{KBr}) \mathrm{v} / \mathrm{cm}^{-1} 3329$, 1665, 1645, 1597, 1510, 1356, 1233; ${ }^{1} \mathrm{H}$ NMR (400 MHz, $\left.\mathrm{CDCl}_{3}\right) \delta 8.21(\mathrm{dd}, 1 \mathrm{H}, J 7.7,1.0 \mathrm{~Hz}, \mathrm{Ar}-\mathrm{H}), 8.16(\mathrm{dd}, 1 \mathrm{H}$, $J$ 7.7, $1.0 \mathrm{~Hz}, \mathrm{Ar}-\mathrm{H}$ ), 7.83 (td, 1H, J 7.5, $1.3 \mathrm{~Hz}, \mathrm{Ar}-\mathrm{H}$ ), 
$7.75(\mathrm{td}, 1 \mathrm{H}, J$ 7.5, $1.3 \mathrm{~Hz}$, Ar-H), 7.57-7.48 (m, 2H, 2Ar-H), 7.21-7.10 (m, 2H, 2Ar-H); ${ }^{13} \mathrm{C}$ NMR (101 MHz, $\left.\mathrm{CDCl}_{3}\right) \delta 183.79,181.84,162.87\left(\mathrm{~d},{ }^{1} J_{C-F} 249 \mathrm{~Hz}\right), 152.36$, $135.49,133.37,132.90,132.83\left(\mathrm{~d},{ }^{3} J_{C-F} 8 \mathrm{~Hz}\right), 129.40$, $127.45,126.32,125.96\left(\mathrm{~d},{ }^{4} J_{C-F} 4 \mathrm{~Hz}\right), 121.25,115.17$ (d, $\left.{ }^{2} J_{C-F} 22 \mathrm{~Hz}\right)$.

2-Hydroxy-3-(4-(trifluoromethyl)phenyl)naphthalene1,4-dione (4d)

After column chromatography using hexanes/EtOAc (85:15) as eluent, this compound was obtained as a yellow solid in 67\% yield, mp 224-227 ${ }^{\circ} \mathrm{C}$; IR (KBr) $v / \mathrm{cm}^{-1} 3333$, $1668,1634,1589,1361,1335,1277,1159,1111 ;{ }^{1} \mathrm{H}$ NMR $\left(400 \mathrm{MHz}, \mathrm{CDCl}_{3}\right) \delta 8.22(\mathrm{~d}, 1 \mathrm{H}, J 7.6 \mathrm{~Hz}, \mathrm{Ar}-\mathrm{H}), 8.18(\mathrm{~d}$, $1 \mathrm{H}, J 7.6 \mathrm{~Hz}, \mathrm{Ar}-\mathrm{H}), 7.85$ (t, 1H, J 7.5 Hz, Ar-H), 7.77 (t, $1 \mathrm{H}, J 7.5 \mathrm{~Hz}, \mathrm{Ar}-\mathrm{H}), 7.72(\mathrm{~d}, 2 \mathrm{H}, J 8.2 \mathrm{~Hz}, 2 \mathrm{Ar}-\mathrm{H}), 7.64$ (d, $2 \mathrm{H}, J 8.2 \mathrm{~Hz}, 2 \mathrm{Ar}-\mathrm{H}) ;{ }^{13} \mathrm{C} \mathrm{NMR}\left(101 \mathrm{MHz},\left(\mathrm{CD}_{3}\right)_{2} \mathrm{CO}\right)$ $\delta$ 183.00, 181.40, 154.67, 135.75, 134.91, 133.21, 132.60, $131.62,130.02,128.97$ (q, $\left.{ }^{2} J_{C-F} 32 \mathrm{~Hz}\right), 126.43,125.70$, $124.50\left(\mathrm{q},{ }^{1} J_{C-F} 271 \mathrm{~Hz}\right), 124.23\left(\mathrm{q},{ }^{3} J_{C-F} 4 \mathrm{~Hz}\right), 120.55$. HRMS (ESI) $\mathrm{m} / z$, calcd. for $\mathrm{C}_{17} \mathrm{H}_{9} \mathrm{~F}_{3} \mathrm{O}_{3}[\mathrm{M}-\mathrm{H}+2 \mathrm{Na}]^{+}$: 363.0215, found: 363.0245 .

\section{4-(3-Hydroxy-1,4-dioxo-1,4-dihydronaphthalen-2-yl)} benzaldehyde (4e)

After column chromatography using hexanes/EtOAc (75:25) as eluent, this compound was obtained as a yellow solid in 58\% yield, $\mathrm{mp} 216-220^{\circ} \mathrm{C}$; IR $(\mathrm{KBr}) \mathrm{V} / \mathrm{cm}^{-1} 3200$, 1688, 1670, 1643, 1605 1359, 1258; 'H NMR (400 MHz, $\left.\mathrm{CDCl}_{3}\right) \delta 10.07$ (s, $\left.1 \mathrm{H}, \mathrm{CHO}\right), 8.22(\mathrm{~d}, 1 \mathrm{H}, J 7.7 \mathrm{~Hz}, \mathrm{Ar}-\mathrm{H})$, 8.19 (d, $1 \mathrm{H}, J 7.5 \mathrm{~Hz}, \mathrm{Ar}-\mathrm{H}), 7.98$ (d, 2H, J $8.2 \mathrm{~Hz}, 2 \mathrm{Ar}-\mathrm{H})$, $7.85(\mathrm{t}, 1 \mathrm{H}, J 7.6 \mathrm{~Hz}, \mathrm{Ar}-\mathrm{H}), 7.78$ (t, 1H, $J .6 \mathrm{~Hz}, \mathrm{Ar}-\mathrm{H})$, $7.75(\mathrm{~s}, 1 \mathrm{H}, \mathrm{OH}), 7.70(\mathrm{~d}, 2 \mathrm{H}, J 8.1 \mathrm{~Hz}, 2 \mathrm{Ar}-\mathrm{H}) ;{ }^{13} \mathrm{C} \mathrm{NMR}$ (101 MHz, DMSO) $\delta 192.94,183.18,181.31,155.47$, 138.06, 135.16, 134.88, 133.41, 131.98, 131.59, 130.05, 128.59, 126.16, 125.77, 120.98. HRMS (ESI) $\mathrm{m} / z$, calcd. for $\mathrm{C}_{17} \mathrm{H}_{10} \mathrm{O}_{4}[\mathrm{M}-\mathrm{H}+2 \mathrm{Na}]^{+}: 323.0291$, found: 323.0290 .

General procedure for the preparation of 2-methoxy3-iodonaphthalene-1,4-dione (5) ${ }^{33}$

To a stirred suspension of $\mathrm{K}_{2} \mathrm{CO}_{3}$ (5 equiv, $2.5 \mathrm{mmol}$ ) in acetone $(12 \mathrm{~mL})$ at room temperature, $2(150 \mathrm{mg}$, $0.5 \mathrm{mmol}$ ) was added. After 5 minutes, dimethyl sulfate ( 2.5 equiv, $1.25 \mathrm{mmol}$ ) was slowly added and then the reaction was heated under reflux overnight. The reaction mixture was cooled to room temperature and ethyl acetate $(25 \mathrm{~mL})$ was added. The organic layer was first washed with brine $(3 \times 25 \mathrm{~mL})$ and then with $\mathrm{H}_{2} \mathrm{O}(3 \times 25 \mathrm{~mL})$, dried over anhydrous $\mathrm{Na}_{2} \mathrm{SO}_{4}$ and concentrated in vacuo. The crude product was purified by flash column chromatography on silica gel using hexanes/EtOAc (90:10) as eluent. This compound was obtained as yellow needles in $74 \%$ yield, mp 160-161 ${ }^{\circ} \mathrm{C}$; IR (KBr) v / $\mathrm{cm}^{-1} 1668,1587,1562,1437$, 1329, 1306, 1248, 1211, 1041, 1007, 914, 719; ${ }^{1} \mathrm{H}$ NMR $\left(500 \mathrm{MHz}, \mathrm{CDCl}_{3}\right) \delta 8.17-8.12(\mathrm{~m}, 1 \mathrm{H}, 1 \mathrm{Ar}-\mathrm{H}), 8.12-8.06$ (m, 1H, 1Ar-H), 7.77-7.64 (m, 2H, 2Ar-H), 4.31 (s, 3H, $\left.\mathrm{OCH}_{3}\right) ;{ }^{13} \mathrm{C}$ NMR $\left(126 \mathrm{MHz}, \mathrm{CDCl}_{3}\right) \delta 179.83,177.84$, $163.48,134.23,133.83,131.02,130.18,127.62,127.04$, $105.58,62.00$.

General procedure for the preparation of 3-iodo-1,4-dioxo1,4-dihydronaphthalen-2-yl acetate (6)

A mixture of $2(150 \mathrm{mg}, 0.5 \mathrm{mmol})$ and 4-dimethylaminopyridine $(20 \mathrm{~mol} \%)$ in acetic anhydride $(2.5 \mathrm{~mL})$ was stirred at room temperature for 4 hours. After this time, ethyl acetate $(25 \mathrm{~mL})$ was added and the organic layer was washed with brine $(3 \times 25 \mathrm{~mL})$, dried over anhydrous $\mathrm{Na}_{2} \mathrm{SO}_{4}$ and concentrated in vacuo. The crude product was purified by flash column chromatography on silica gel using hexanes/EtOAc $(80: 20)$ as eluent. This compound was obtained as a yellow solid in $70 \%$ yield, mp 153-154 ${ }^{\circ} \mathrm{C}$; IR ( $\left.\mathrm{KBr}\right) v / \mathrm{cm}^{-1} 1778,1674,1597,1371$, $1327,1302,1275,1244,1165,721 ;{ }^{1} \mathrm{H}$ NMR $(500 \mathrm{MHz}$, $\left.\mathrm{CDCl}_{3}\right) \delta$ 8.22-8.18 (m, 1H, Ar-H), 8.16-8.12 (m, 1H, Ar-H), 7.81-7.73 (m, 2H, 2Ar-H), 2.46 (s, 3H, OAc); ${ }^{13} \mathrm{C}$ NMR $\left(126 \mathrm{MHz}, \mathrm{CDCl}_{3}\right) \delta 179.09,174.97,166.63$, $158.90,134.55,134.50,130.51,130.47,128.30,127.53$, $113.88,20.75$. HRMS (ESI) $\mathrm{m} / z$, calcd. for $\mathrm{C}_{12} \mathrm{H}_{7} \mathrm{IO}_{4}$ $[\mathrm{M}+\mathrm{Na}]^{+}:$364.9281, found: 364.9276 .

General procedure for the preparation of 1,4-dioxo-3-aryl1,4-dihydronaphthalen-2-yl diethylcarbamates (7a-e) and 3-(3-methylbut-2-en-1-yl)-1,4-dioxo-1,4-dihydronaphthalen2-yl diethylcarbamate (8)

A stirred solution of $\mathbf{1}(0.1 \mathrm{mmol})$ or $\mathbf{4}(0.1 \mathrm{mmol})$, pyridine (5 equiv), $N, N$-diethylcarbamoyl chloride (20 equiv), in $\mathrm{CHCl}_{3}(10 \mathrm{~mL})$ was heated at $60{ }^{\circ} \mathrm{C}$ for 18 hours. Dichloromethane $(30 \mathrm{~mL})$ was added to the reaction mixture and the organic layer was first washed with a solution of hydrochloric acid $1 \mathrm{~N}(30 \mathrm{~mL})$ and then with brine $(3 \times 30 \mathrm{~mL})$, dried over anhydrous $\mathrm{Na}_{2} \mathrm{SO}_{4}$ and concentrated in vacuo. The crude product was purified by flash column chromatography on silica gel.

1,4-Dioxo-3-phenyl-1,4-dihydronaphthalen-2-yl diethylcarbamate $(\mathbf{7 a})$

After column chromatography using hexanes/EtOAc (95:5) as eluent, this compound was obtained as an orange solid in $38 \%$ yield, $\mathrm{mp} 90-93{ }^{\circ} \mathrm{C}$; IR (neat) $\mathrm{v} / \mathrm{cm}^{-1} 1730$, 
1666, 1595, 1471, 1257, 1184, 1146; ${ }^{1} \mathrm{H}$ NMR (500 MHz, $\left.\mathrm{CDCl}_{3}\right) \delta 8.19-8.13(\mathrm{~m}, 2 \mathrm{H}, 2 \mathrm{Ar}-\mathrm{H}), 7.79-7.73(\mathrm{~m}, 2 \mathrm{H}$, 2Ar-H), 7.48-7.37 (m, 5H, 5Ar-H), 3.37-3.24 (m, 4H, $\left.2 \mathrm{CH}_{2}\right), 1.17\left(\mathrm{t}, 3 \mathrm{H}, J 7.1 \mathrm{~Hz}, \mathrm{CH}_{3}\right), 1.06(\mathrm{t}, 3 \mathrm{H}, J 7.1 \mathrm{~Hz}$, $\left.\mathrm{CH}_{3}\right) ;{ }^{13} \mathrm{C}$ NMR $\left(126 \mathrm{MHz}, \mathrm{CDCl}_{3}\right) \delta 184.36,179.91$, 152.67, 150.67, 136.81, 134.33, 133.94, 132.18, 131.15, 130.16, 129.56, 129.24, 128.02, 127.08, 126.60, 42.54, 42.50, 13.85, 13.29. HRMS (ESI) $\mathrm{m} / z$, calcd. for $\mathrm{C}_{21} \mathrm{H}_{19} \mathrm{NO}_{4}$ $[\mathrm{M}+\mathrm{Na}]^{+}:$372.1206, found: 372.1209 .

3-(3,4-Dimethoxyphenyl)-1,4-dioxo-1,4-dihydronaphthalen2-yl diethylcarbamate (7b)

After column chromatography using hexanes/EtOAc (95:5) as eluent, this compound was obtained as a red solid in $44 \%$ yield, $\mathrm{mp} 115-118{ }^{\circ} \mathrm{C}$; IR (neat) $\mathrm{v} / \mathrm{cm}^{-1} 1730$, 1666, 1595, 1514, 1454, 1259, 1184, 1145, 1026; ${ }^{1} \mathrm{H}$ NMR $\left(500 \mathrm{MHz}, \mathrm{CDCl}_{3}\right) \delta 8.20-8.12(\mathrm{~m}, 2 \mathrm{H}, 2 \mathrm{Ar}-\mathrm{H}), 7.81-7.73$ (m, 2H, 2Ar-H), 7.04 (dd, 1H, J 8.3, 2.0 Hz, Ar-H), 7.00 (d, 1H, J $2.0 \mathrm{~Hz}, \mathrm{Ar}-\mathrm{H}$ ), 6.95 (d, 1H, J 8.3 Hz, Ar-H), 3.94 (s, $\left.3 \mathrm{H}, \mathrm{OCH}_{3}\right), 3.88\left(\mathrm{~s}, 3 \mathrm{H}, \mathrm{OCH}_{3}\right), 3.44-3.24\left(\mathrm{~m}, 4 \mathrm{H}, 2 \mathrm{CH}_{2}\right)$, $1.20\left(\mathrm{t}, 3 \mathrm{H}, J 7.1 \mathrm{~Hz}, \mathrm{CH}_{3}\right), 1.12$ (t, $\left.3 \mathrm{H}, J 7.1 \mathrm{~Hz}, \mathrm{CH}_{3}\right)$; ${ }^{13} \mathrm{C}$ NMR $\left(126 \mathrm{MHz}, \mathrm{CDCl}_{3}\right) \delta 184.59,179.88,152.92$, 150.34, 150.01, 148.48, 136.61, 134.26, 133.93, 132.27, 131.20, 127.11, 126.56, 123.67, 121.95, 113.45, 110.72, 55.05, 55.99, 42.58, 14.01, 13.37. HRMS (ESI) $\mathrm{m} / z$, calcd. for $\mathrm{C}_{23} \mathrm{H}_{23} \mathrm{NO}_{6}[\mathrm{M}+\mathrm{Na}]^{+}:$432.1418, found: 432.1422 .

\section{3-(4-Fluorophenyl)-1,4-dioxo-1,4-dihydronaphthalen-2-yl diethylcarbamate (7c)}

After column chromatography using hexanes/EtOAc (95:5) as eluent, this compound was obtained as a yellow oil in $73 \%$ yield. IR (neat) $\mathrm{v} / \mathrm{cm}^{-1} 1730,1666,1593,1504$, $1259,1225,1184,1145 ;{ }^{1} \mathrm{H}$ NMR $\left(500 \mathrm{MHz}, \mathrm{CDCl}_{3}\right)$ $\delta$ 8.20-8.12 (m, 2H, 2Ar-H), 7.81-7.74 (m, 2H, 2Ar-H), 7.44-7.39 (m, 2H, 2Ar-H), 7.17-7.11 (m, 2H, 2Ar-H), 3.38-3.28 (m, 4H, 2CH $), 1.19$ (t, 3H, J $7.1 \mathrm{~Hz}, \mathrm{CH}_{3}$ ), $1.10\left(\mathrm{t}, 3 \mathrm{H}, J 7.1 \mathrm{~Hz}, \mathrm{CH}_{3}\right) ;{ }^{13} \mathrm{C} \mathrm{NMR}\left(126 \mathrm{MHz}, \mathrm{CDCl}_{3}\right)$ $\delta 184.25,179.73,163.26\left(\mathrm{~d},{ }^{1} J_{C-F} 249 \mathrm{~Hz}\right), 152.59,150.70$, 135.74, 134.41, 134.04, 132.28 (d, $\left.{ }^{3} J_{C-F} 8 \mathrm{~Hz}\right), 132.01$, 131.04, 127.09, 126.63, $125.37\left(\mathrm{~d},{ }^{4} J_{C-F} 3 \mathrm{~Hz}\right), 115.22$ (d, $\left.{ }^{2} J_{C-F} 22 \mathrm{~Hz}\right), 42.56,42.51,13.92,13.29$. HRMS (ESI) $\mathrm{m} / z$, calcd. for $\mathrm{C}_{21} \mathrm{H}_{18} \mathrm{FNO}_{4}[\mathrm{M}+\mathrm{Na}]^{+}: 390.1112$, found: 390.1116.

1,4-Dioxo-3-(4-(trifluoromethyl)phenyl)-1,4-dihydronaphthalen-2-yl diethylcarbamate (7d)

After column chromatography using hexanes/EtOAc (95:5) as eluent, this compound was obtained as a yellow oil in $48 \%$ yield. IR (neat) $\mathrm{v} / \mathrm{cm}^{-1} 1730,1666,1595,1330$, $1257,1184,1144,1067,1018 ;{ }^{1} \mathrm{H} N M R\left(500 \mathrm{MHz}, \mathrm{CDCl}_{3}\right)$ $\delta$ 8.21-8.14 (m, 2H, 2Ar-H), 7.82-7.76 (m, 2H, 2Ar-H), $7.71(\mathrm{~d}, 2 \mathrm{H}, J 8.0 \mathrm{~Hz}, 2 \mathrm{Ar}-\mathrm{H}), 7.54(\mathrm{~d}, 2 \mathrm{H}, J 8.0 \mathrm{~Hz}$, $2 \mathrm{Ar}-\mathrm{H}), 3.38-3.26\left(\mathrm{~m}, 4 \mathrm{H}, 2 \mathrm{CH}_{2}\right), 1.18(\mathrm{t}, 3 \mathrm{H}, J 7.1 \mathrm{~Hz}$, $\left.\mathrm{CH}_{3}\right), 1.08\left(\mathrm{t}, 3 \mathrm{H}, J 7.1 \mathrm{~Hz}, \mathrm{CH}_{3}\right) ;{ }^{13} \mathrm{C}$ NMR $(126 \mathrm{MHz}$, $\left.\mathrm{CDCl}_{3}\right) \delta 183.84,179.58,152.42,151.23,135.46,134.54$, 134.17, 133.37, 132.00, 131.14 (q, $\left.{ }^{2} J_{C-F} 33 \mathrm{~Hz}\right), 131.10$, $130.65,127.15,126.75,124.98$ (q, $\left.{ }^{3} J_{C-F} 4 \mathrm{~Hz}\right), 124.09$ (q, ${ }^{1} J_{C-F} 272 \mathrm{~Hz}$ ), 42.66, 42.61, 13.84, 13.22. HRMS (ESI) $\mathrm{m} / \mathrm{z}$, calcd. for $\mathrm{C}_{22} \mathrm{H}_{18} \mathrm{~F}_{3} \mathrm{NO}_{4}[\mathrm{M}+\mathrm{Na}]^{+}: 440.1080$, found: 440.1079 .

3-(4-Formylphenyl)-1,4-dioxo-1,4-dihydronaphthalen-2-yl diethylcarbamate (7e)

After column chromatography using hexanes/EtOAc (95:5) as eluent, this compound was obtained as a yellow oil in $32 \%$ yield. IR (neat) $\mathrm{v} / \mathrm{cm}^{-1} 1730,1694,1666,1605$, 1259, 1209, 1184, 1145; ${ }^{1} \mathrm{H}$ NMR $\left(500 \mathrm{MHz}, \mathrm{CDCl}_{3}\right)$ $\delta 10.08$ (s, 1H, C $2 \mathrm{H}, J 8.2 \mathrm{~Hz}, 2 \mathrm{Ar}-\mathrm{H}), 7.83-7.77$ (m, 2H, 2Ar-H), 7.60 (d, $2 \mathrm{H}, J 8.2 \mathrm{~Hz}, 2 \mathrm{Ar}-\mathrm{H}), 3.40-3.24\left(\mathrm{~m}, 4 \mathrm{H}, 2 \mathrm{CH}_{2}\right), 1.18(\mathrm{t}$, $\left.3 \mathrm{H}, J 7.1 \mathrm{~Hz}, \mathrm{CH}_{3}\right), 1.07$ (t, $\left.3 \mathrm{H}, J 7.1 \mathrm{~Hz}, \mathrm{CH}_{3}\right) ;{ }^{13} \mathrm{C} \mathrm{NMR}$ $\left(126 \mathrm{MHz}, \mathrm{CDCl}_{3}\right) \delta 191.98,183.76,179.53,152.40$, 151.16, 136.52, 135.86, 135.59, 134.56, 134.18, 131.98, 131.07, 130.98, 129.21, 127.14, 126.76, 42.67, 42.60, 13.91, 13.22. HRMS (ESI) $\mathrm{m} / \mathrm{z}$, calcd. for $\mathrm{C}_{22} \mathrm{H}_{19} \mathrm{NO}_{5}$ $[\mathrm{M}+\mathrm{Na}]^{+}:$400.1155, found: 400.1164 .

3-(3-Methylbut-2-en-1-yl)-1,4-dioxo-1,4-dihydronaphthalen2-yl diethylcarbamate (8)

After column chromatography using hexanes/EtOAc (95:5) as eluent, this compound was obtained as a brown oil in $40 \%$ yield. IR (neat) $\mathrm{v} / \mathrm{cm}^{-1} 1730,1694,1666$, 1593, 1454, 1360, 1337, 1259, 1186, 1145, 1051; ${ }^{1} \mathrm{H}$ NMR (500 MHz, $\left.\mathrm{CDCl}_{3}\right) \delta 8.13-8.03$ (m, 2H, 2Ar-H), 7.77-7.66 $(\mathrm{m}, 2 \mathrm{H}, 2 \mathrm{Ar}-\mathrm{H}), 5.17-5.11(\mathrm{~m}, 1 \mathrm{H}, \mathrm{CH}), 3.48(\mathrm{q}, 2 \mathrm{H}$, $\left.J 7.1 \mathrm{~Hz}, \mathrm{CH}_{2}\right), 3.41\left(\mathrm{q}, 2 \mathrm{H}, J 7.1 \mathrm{~Hz}, \mathrm{CH}_{2}\right), 3.32(\mathrm{~d}, 2 \mathrm{H}$, $\left.J 7.3 \mathrm{~Hz}, \mathrm{CH}_{2}\right), 1.76\left(\mathrm{~s}, 3 \mathrm{H}, \mathrm{CH}_{3}\right), 1.68\left(\mathrm{~s}, 3 \mathrm{H}, \mathrm{CH}_{3}\right)$, 1.32 (t, $\left.3 \mathrm{H}, J 7.1 \mathrm{~Hz}, \mathrm{CH}_{3}\right), 1.24$ (t, 3H, J 7.1 Hz, $\left.\mathrm{CH}_{3}\right)$; ${ }^{13} \mathrm{C}$ NMR $\left(126 \mathrm{MHz}, \mathrm{CDCl}_{3}\right) \delta 184.96,179.67,152.53$, 151.27, 137.81, 134.50, 134.02, 133.71, 132.33, 131.19, 126.70, 126.57, 119.07, 42.61, 25.89, 23.72, 18.04, 14.17, 13.34. HRMS (ESI) $m / z$, calcd. for $\mathrm{C}_{20} \mathrm{H}_{23} \mathrm{NO}_{4}[\mathrm{M}+\mathrm{Na}]^{+}$: 364.1519, found: 364.1520 .

\section{Antineoplastic activity}

The cell lines HL-60 and K562 were obtained from the National Cancer Institute, Bethesda, MD, USA. All cancer cells were maintained in RPMI 1640 (Roswell Park Memorial Institute 1640) medium supplemented with $10 \%$ fetal bovine serum, $2 \mathrm{mM}$ glutamine, $100 \mathrm{U} \mathrm{mL}^{-1}$ penicillin, $100 \mu \mathrm{g} \mathrm{mL}-1$ streptomycin at $37{ }^{\circ} \mathrm{C}$ with $5 \%$ 
$\mathrm{CO}_{2}$. Heparinized blood (from healthy, non-smoker donors who had not taken any drug at least 15 days prior to sampling) was collected and PBMC were isolated by a standard method of density-gradient centrifugation over Ficoll-Hypaque. PBMC were washed, resuspended at a concentration of $3 \times 10^{5}$ cells $\mathrm{mL}^{-1}$ and plated in a 96-well plate with RPMI 1640 medium supplemented with $20 \%$ fetal bovine serum, $2 \mathrm{mM}$ glutamine, $100 \mathrm{U} \mathrm{mL}^{-1}$ penicillin, $100 \mu \mathrm{g} \mathrm{mL}-1$ streptomycin at $37{ }^{\circ} \mathrm{C}$ with $5 \%$ $\mathrm{CO}_{2}$. Phytohemagglutinin (3\%) was added at the beginning of culture. After $24 \mathrm{~h}$, tested compounds $(0.4-80 \mu \mathrm{M})$ dissolved in RPMI 1640 medium with $1 \%$ of DMSO (dimethyl sulfoxide) were added to each well and incubated for $72 \mathrm{~h}$.

The cytotoxicity of all compounds were tested using the 3-(4,5-dimethyl-2-thiazolyl)-2,5-diphenyl- $2 \mathrm{H}$-tetrazolium bromide (MTT) ${ }^{34}$ (Sigma-Aldrich Co., St. Louis, MO, USA) reduction assay. For all experiments, tumor cells were plated in 96-well plates $\left(3 \times 10^{5}\right.$ cells $\left.\mathrm{mL}^{-1}\right)$. Tested compounds $(0.4-80 \mu \mathrm{M})$ dissolved in DMSO $1 \%$ were added to each well and incubated for $72 \mathrm{~h}$. Control groups received the same amount of DMSO. At the end of the incubation, the plates were centrifuged and the medium was replaced by fresh medium $(150 \mu \mathrm{L})$ containing $0.5 \mathrm{mg} \mathrm{mL}^{-1}$ MTT. After $3 \mathrm{~h}$, the formazan product was dissolved in $150 \mu \mathrm{L}$ of DMSO, and the absorbance was measured using a multiplate reader (DTX 880 Multimode Detector, Beckman Coulter, Inc., Fullerton, California, USA). The $\mathrm{IC}_{50}$ values and their $95 \%$ confidence intervals for two different experiments were obtained by nonlinear regression using GraphPad Prism version 5.0 for Windows (GraphPad Software, San Diego, California, USA).

\section{Antileishmanial activity}

The compounds were dissolved in DMSO, Sigma ${ }^{\circledR}$. Assay concentrations were prepared in culture medium used in the experiments, as indicated in each case. For antipromastigote activity, ${ }^{10}$ promastigotes of Leishmania amazonensis (MHOM/BR/75/LTB0016) were adjusted to a concentration of $1 \times 10^{6}$ cells $\mathrm{mL}^{-1}$ in Schneider medium supplemented with $10 \%$ de fetal bovine serum, penicillin $\left(100 \mathrm{U} \mathrm{mL}^{-1}\right)$ and streptomycin $\left(100 \mu \mathrm{g} \mathrm{mL} L^{-1}\right)$, and incubated at $26^{\circ} \mathrm{C}$ for $72 \mathrm{~h}$ with the compounds $(0-100 \mu \mathrm{M})$. The antileishmanial activity was evaluated by adding in each well $22 \mu \mathrm{L}$ of MTT at $5 \mathrm{mg} \mathrm{mL}^{-1}\left(\right.$ Sigma $\left.^{\circledR}\right)$. After $2 \mathrm{~h}, 80 \mu \mathrm{L}$ of DMSO was added. The optical density was determined at a wavelength of $570 \mathrm{~nm}$ in microplate reader ( $\mu$ Quant Bio-Tek Instruments ${ }^{\circledR}$, Winooski, Vermont, USA). The inhibition percentage was estimated by the comparison with non-treated control cultures. The assays were carried out in triplicate in 96-well plates (Costar ${ }^{\circledR}$, New York, NY, USA) and repeated at least three times. For intracellular amastigote assays, BALB/c mice macrophages were obtained by peritoneal lavage with $5 \mathrm{~mL}$ of cold RPMI medium (Sigma ${ }^{\circledR}$ ). The cell suspension $\left(2 \times 10^{6}\right.$ macrophages $\left.\mathrm{mL}^{-1}\right)$ was applied in Labtek chambers (Nunc ${ }^{\circledR}$, New York, NY, USA) and incubated for $1 \mathrm{~h}$ at $37{ }^{\circ} \mathrm{C}, 5 \% \mathrm{CO}_{2}$. Then, the cultures were washed with phosphate buffer saline (PBS) at $37{ }^{\circ} \mathrm{C}$ for removal of non-adherent cells. The remaining cells were incubated at $37^{\circ} \mathrm{C}, 5 \% \mathrm{CO}_{2}$ with stationary phase promastigotes of L. amazonensis at a ratio of $3: 1$. After $3 \mathrm{~h}$, the chambers were washed again to remove free parasites and incubated with compounds $(0-50 \mu \mathrm{M})$ at $37{ }^{\circ} \mathrm{C}, 5 \% \mathrm{CO}_{2}$ for $72 \mathrm{~h}$. The antiamastigote activity was analyzed microscopically by counting at least 100 macrophages per sample, after staining cells with hematological system Instant Prov (New Prov ${ }^{\circledR}$, Curitiba, Brazil). ${ }^{35}$ The experiments were performed in duplicate and repeated twice. Results were expressed as infection index (II) using the following formula: $\mathrm{II}=(\%$ infected cells $) \times($ number of amastigotes / total macrophages number). For toxicity assays, BALB/c mice macrophages were obtained by peritoneal lavage with $5 \mathrm{~mL}$ of cold RPMI medium (Sigma ${ }^{\circledR}$ ). The macrophages at $2 \times 10^{6}$ cells well $^{-1}$ in RPMI culture medium $(\mathrm{pH} 7.2$, supplemented with $10 \%$ fetal bovine serum) were incubated with the compounds $(0-200 \mu \mathrm{M})$ for $72 \mathrm{~h}$ at $37{ }^{\circ} \mathrm{C}$ under $5 \% \mathrm{CO}_{2}$ in 96 -well plates. After removing the supernatant, viable cells were quantified by adding MTT $(200 \mu \mathrm{L}$, $0.5 \mathrm{mg} \mathrm{mL}^{-1}$ ) in PBS. After $2 \mathrm{~h}$, the supernatant was removed and DMSO $(100 \mu \mathrm{L})$ was added in each well. The optical density was determined at wavelength of $570 \mathrm{~nm}$ in the microplate reader. The percentage of viable cells was calculated relative to the control cells. The tests were carried out in triplicate and repeated twice. Logarithm regression analysis was performed using GraphPad Prism 5.0 (San Diego, CA, USA) in order to obtain the values of $\mathrm{IC}_{50}$ and $\mathrm{LD}_{50}$. The selectivity index was determined as macrophage $\mathrm{LD}_{50}$ /intracellular amastigote $\mathrm{IC}_{50}$. This study was approved by the Animal Ethics Committee of Oswaldo Cruz Foundation (license number LW7/2010).

\section{Supplementary Information}

Supplementary data $\left({ }^{1} \mathrm{H}\right.$ and ${ }^{13} \mathrm{C}$ NMR spectra) are available free of charge at http://jbcs.sbq.org.br as PDF file.

\section{Acknowledgments}

This research was supported by FINEP, FUNCAP, Programa de Oncobiologia-UFRJ, PRONEX, FAPERJ, 
CNPq and CAPES. We are grateful to LAMAR and IPPNUFRJ for the analytical data.

\section{References}

1. Thomson, R. H.; Naturally Occurring Quinones, $2^{\text {nd }}$ ed.; Academic: London, England, 1971; Thomson, R. H.; Naturally Occurring Quinones IV: Recent Advances, $4^{\text {th }}$ ed.; Blackie: London, 1997; Morton, R. A.; Biochemistry of Quinones, $1^{\text {st }}$ ed.; Academic: London, England, 1965; Hillard, E. A.; de Abreu, F. C.; Ferreira, D. C. M.; Jaouen, G.; Goulart, M. O. F.; Amatore, C.; Chem. Commun. 2008, 2612; Wellington, K. W.; RSC Adv. 2015, 5, 20309.

2. Linardi, M. C. F.; de Oliveira, M. M.; Sampaio, M. R. P.; J. Med. Chem. 1975, 18, 1159; Portela, M. P. M.; Stoppani, A. O. M.; Biochem. Pharmacol. 1996, 51, 275; O’Brien, P. J.; Chem. Biol. Interact. 1991, 80, 1; Salas, C.; Tapia, R. A.; Ciudad, K.; Armstrong, V.; Orellana, M.; Kemmerling, U.; Ferreira, J.; Maya, J. D.; Morello, A.; Bioorg. Med. Chem. 2008, 16, 668; Johnson, L. E.; Dietz, A.; Appl. Microbiol. 1968, 16, 1815; Donner, C. D.; Tetrahedron Lett. 2007, 48, 8888; da Silva, F. C.; Ferreira, V. F.; Curr. Org. Synth. 2016, 13, 334.

3. Bradner, W. T.; Cancer Treat. Rev. 2001, 27, 35; Galm, U.; Hager, M. H.; Van Lanen, S. G.; Ju, J.; Thorson, J. S.; Shen, B.; Chem. Rev. 2005, 105, 739.

4. Tacar, O.; Sriamornsak, P.; Dass, C. R.; J. Pharm. Pharmacol. 2013, 65, 157.

5. Baggish, A. L.; Hill, D. R.; Antimicrob. Agents Chemother. 2002, 46, 1163; Nixon, G. L.; Moss, D. M.; Shone, A. E.; Lalloo, D. G.; Fischer, N.; O’Neil, P. M.; Ward, S. A.; Biagini, G. A.; J. Antimicrob. Chemother. 2013, 68, 977.

6. Hussain, H.; Krohn, K.; Ahmad, V. U.; Miana, G. A.; Green, I. R.; ARKIVOC 2007, ii, 145; Epifano, F.; Genovese, S.; Fiorito, S.; Mathieu, V.; Kiss, R.; Phytochem. Rev. 2014, 13, 37.

7. Ikushima, H.; Iguchi, E.; Kohsaka, M.; Aoki, H.; Imanaka, H.; J. Antibiot. 1980, 33, 1103; Ikushima, H.; Okamoto, M.; Tanaka, H.; Ohe, O.; Kohsaka, M.; Aoki, H.; Imanaka, H.; J. Antibiot. 1980, 33, 1107; Qabaja, G.; Perchellet, E. M.; Perchellet, J.-P.; Jones, G. B.; Tetrahedron Lett. 2000, 41, 3007; Hu, G.; Li, X.; Li, Y.; Sun, X.; Liu, G.; Li, W.; Huang, J.; Shen, X.; Tang, Y.; Chin. J. Chem. 2012, 30, 2752.

8. Alnassan, A. A.; Thabet, A.; Daugschies, A.; Bangoura, B.; Parasitol. Res. 2015, 114, 3913.

9. da Silva, A. J. M.; Buarque, C. D.; Brito, F. V.; Aurelian, L.; Macedo, L. F.; Malkas, L. H.; Hickey, R. J.; Lopes, D. V. S.; Noël, F.; Murakami, Y. L. B.; Silva, N. M. V.; Melo, P. A.; Caruso, R. R. B.; Castro, N. G.; Costa, P. R. R.; Bioorg. Med. Chem. 2002, 10, 2731; Sacau, E. P.; Estévez-Braun, A.; Ravelo, A. G.; Ferro, E. A.; Tokuda, H.; Mukainaka, T.; Nishino, H.; Bioorg. Med. Chem. 2003, 11, 483; Andrade-Neto, V. F.; Goulart, M. O. F.; Filho, J. F. S.; da Silva, M. J.; Pinto, M. C.
F. R.; Pinto, A. V.; Zalis, M. G.; Carvalho, L. H.; Krettli, A. U.; Bioorg. Med. Chem. Lett. 2004, 14, 1145; Eyong, K. O.; Kumar, P. S.; Kuete, V.; Folefoc, G. N.; Nkengfack, E. A.; Baskaran, S.; Bioorg. Med. Chem. Lett. 2008, 18, 5387; Pinto, A. V.; de Castro, S. L.; Molecules 2009, 14, 4570.

10. Buarque, C. D.; Militão, G. C. G.; Lima, D. J. B.; Costa-Lotufo, L. V.; Pessoa, C.; de Moraes, M. O.; Cunha-Junior, E. F.; TorresSantos, E. C.; Netto, C. D.; Costa, P. R. R.; Bioorg. Med. Chem. 2011, 19, 6885.

11. da Silva, A. J. M.; Coelho, A. L.; Simas, A. B. C.; Moraes, R. A. M.; Pinheiro, D. A.; Fernandes, F. F. A.; Arruda, E. Z.; Costa, P. R. R.; Melo, P. A.; Bioorg. Med. Chem. Lett. 2004, 14, 431; Lima, L. M.; Barreiro, E. J.; Curr. Med. Chem. 2005, 12, 23.

12. Férriz, J. M.; Vávrová, K.; Kunc, F.; Imramovský, A.; Stolaríková, J.; Vavríková, E.; Vinšová, J.; Bioorg. Med. Chem. 2010, 18, 1054; Hemaa, M. R.; Ramaiaha, M.; Vaidyab, V. P.; Shivakumara, B. S.; Suresha, G. S.; J. Chem. Pharm. Res. 2013, 5, 47; Janganati, V.; Penthala, N. R.; Madadi, N. R.; Chen, Z.; Crooks, P. A.; Bioorg. Med. Chem. Lett. 2014, 24, 3499; Krátký, M.; Volková, M.; Novotná, E.; Trejtnar, F.; Stolaríková, J.; Vinšová, J.; Bioorg. Med. Chem. 2014, 22, 4073.

13. Vane, J. R.; Botting, R. M.; Thromb. Res. 2003, 110, 255.

14. Rautio, J.; Kumpulainen, H.; Heimbach, T.; Oliyai, R.; Oh, D.; Järvinen, T.; Savolainen, J.; Nat. Rev. Drug Discovery 2008, 7 , 255.

15. Klinkert, M.-Q.; Heussler, V.; Mini-Rev. Med. Chem. 2006, 6, 131; Fuertes, M. A.; Nguewa, P. A.; Castilla, J.; Alonso, C.; Pérez, J. M.; Curr. Med. Chem. 2008, 15, 433.

16. Stagliano, K. W.; Malinakova, H. C.; J. Org. Chem. 1999, 64, 8034; Emadi, A.; Hardwood, J. S.; Kohanim, S.; Stagliano, K. W.; Org. Lett. 2002, 4, 521.

17. Kazantzi, G.; Malamidou-Xenikaki, E.; Spyroudis, S.; Synlett 2006, 2597.

18. Glinis, E.; Malamidou-Xenikaki, E.; Skouros, H.; Spyroudis, S.; Tsanakopoulou, M.; Tetrahedron 2010, 66, 5786.

19. Patil, P.; Nimonkar, A.; Akamanchi, K. G.; J. Org. Chem. 2014, 79, 2331.

20. Ilangovan, A.; Polu, A.; Satish, G.; Org. Chem. Front. 2015, 2 , 1616.

21. Suzuki, A.; Miyaura, N.; Chem. Rev. 1995, 95, 2457; Kotha, S.; Lahiri, K.; Kashinath, D.; Tetrahedron 2002, 58, 9633; Lennox, A. J. J.; Lloyd-Jones, G. C.; Chem. Soc. Rev. 2014, 43, 412; Biajoli, A. F. P.; Schwalm, C. S.; Limberger, J.; Claudino, T. S.; Monteiro, A. L.; J. Braz. Chem. Soc. 2014, 25, 2186.

22. Louvis, A. R.; Silva, N. A. A.; Semaan, F. S.; Silva, F. C.; Saramago, G.; Souza, L. C. S. V.; Ferreira, B. L. A.; Castro, H. C.; Salles, J. P.; Souza, A. L. A.; Faria, R. X.; Ferreira, V. F.; Martins, D. L.; New J. Chem. 2016, 40, 7643.

23. da Frota, L. C. R. M.; Canavez, R. C. P.; Gomes, S. L. S.; Costa, P. R. R.; da Silva, A. J. M.; J. Braz. Chem. Soc. 2009, 10, 1916. 24. Watanabe, T.; Miyaura, N.; Suzuki, A.; Synlett 1992, 207. 
25. Pousse, G.; Devineau, A.; Dalla, V.; Humphreys, L.; Lasne, M.; Rouden, J.; Blanchet, J.; Tetrahedron 2009, 65, 10617.

26. Bonifazi, E. L.; Ríos-Luci, C.; León, L. G.; Burton, G.; Padrón, J. M.; Misico, R. I.; Bioorg. Med. Chem 2010, 18, 2621.

27. van der Klei, A.; de Jong, R. L. P.; Lugtenburg, J.; Tielens, A. G. M.; Eur. J. Org. Chem. 2002, 3015.

28. Wuts, P. G. M.; Greene, T. W.; Protective Groups in Organic Synthesis, $4^{\text {th }}$ ed.; Wiley: New Jersey, USA, 2007.

29. Netto, C. D.; da Silva, A. J. M.; Salustiano, E. J. S.; Bacelar, T. S.; Riça, I. G.; Cavalcante, M. C. M.; Rumjanek, V. M.; Costa, P. R. R.; Bioorg. Med. Chem. 2010, 18, 1610; Salustiano, E. J. S.; Netto, C. D.; Fernandes, R. F.; da Silva, A. J. M.; Bacelar, T. S.; Castro, C. P.; Buarque, C. D.; Maia, R. C.; Rumjanek, V. M.; Costa, P. R. R.; Invest. New Drugs 2010, 28, 139.

30. Katsuno, K.; Burrows, J. N.; Duncan, K.; van Huijsduijnen, R. H.; Kaneko, T.; Kita, K.; Mowbray, C. E.; Schmatz, D.; Warner, P.; Slingsby, B. T.; Nat. Rev. Drug Discovery 2015, 14, 751.
31. Allan, K. M.; Hong, B. D.; Stoltz, B. M.; Org. Biomol. Chem. 2009, 7, 4960.

32. Fieser, L. F.; Berliner, E.; Bondhus, F. J.; Chang, F. C.; Dauben, W. G.; Ettlinger, M. G.; Fawas, G.; Fields, M.; Heidelberger, C.; Heymann, H.; Vaughan, W. R.; Wilson, A. G.; Wilson, E.; Wu, M.-I.; Leffler, M. T.; Hamlin, K. E.; Matson, E. J.; Moore, E. E.; Moore, M. B.; Zaugg, H. E.; J. Am. Chem. Soc. 1948, 70, 3203.

33. Sharma, J.; Singh, P. K.; Singh, K. P.; Khanna, R. N.; Org. Prep. Proced. Int. 1995, 27, 84.

34. Mosmann, T.; J. Immunol. Methods 1983, 65, 55.

35. Torres-Santos, E. C.; Moreira, D. L.; Kaplan, M. A. C.; Meirelles, M. N.; Rossi-Bergaman, B.; Antimicrob. Agents Chemother. 1999, 43, 1234

Submitted: July 14, 2016

Published online: December 20, 2016 